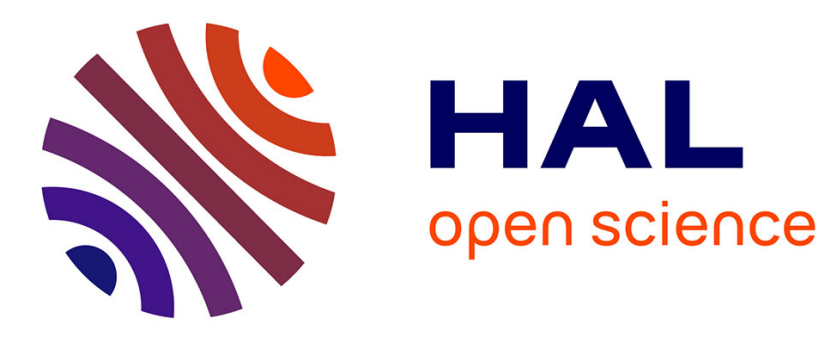

\title{
Biomechanical analysis and modeling of lumbar belt: parametric study
}

Rébecca Bonnaire, Woo Suck Han, Jérôme Molimard, Paul Calmels, Reynald Convert

\section{- To cite this version:}

Rébecca Bonnaire, Woo Suck Han, Jérôme Molimard, Paul Calmels, Reynald Convert. Biomechanical analysis and modeling of lumbar belt: parametric study. Computer Methods in Biomechanics and Biomedical Engineering, 2014, 17 suppl 1, pp.62 - 63. 10.1080/10255842.2014.931123 . emse01108661

\section{HAL Id: emse-01108661 \\ https://hal-emse.ccsd.cnrs.fr/emse-01108661}

Submitted on 23 Jan 2015

HAL is a multi-disciplinary open access archive for the deposit and dissemination of scientific research documents, whether they are published or not. The documents may come from teaching and research institutions in France or abroad, or from public or private research centers.
L'archive ouverte pluridisciplinaire HAL, est destinée au dépôt et à la diffusion de documents scientifiques de niveau recherche, publiés ou non, émanant des établissements d'enseignement et de recherche français ou étrangers, des laboratoires publics ou privés. 


\title{
Biomechanical analysis and modeling of lumbar belt: parametric study.
}

\author{
R. Bonnaire $\uparrow \dagger$, W.S. Han* $\uparrow$, J. Molimard $\dagger$, P. Calmels• and R. Convert $\ddagger$ \\ $\dagger$ Center for Biomedical and Healthcare Engineering, Ecole Nationale Supérieur des Mines de St-Etienne, 158 cours \\ Fauriel, 42023 St-Etienne, France
}

¥ Thuasne, 27 rue de la Jomayère, 42032 St-Etienne France

-Physical medicine and rehabilitation CHU Bellevue, 25 boulevard Pasteur, 42055 St-Etienne, France

Keywords: Low back pain; Finite element; Lumbar belt; Parametric study

\section{Introduction}

Low back pain is a major public health problem in European Countries. In France, about $50 \%$ of population is suffering of this pathology every year [Fassier, 2011]. Because of health care cost and sick leave [Fassier, 2011], [Leclerc, 2009], low back pain as both societal and economic adverse consequences. Concerning medical devices, such as lumbar belts, several clinical trials have shown their efficiency [Calmels, 1999]. It might be essential to know which parameters are important so as to increase the efficiency of their medical effects on patients. Nevertheless, both mechanical and physiological effects of lumbar belts remain unclear. In this study, a parametrical method is used in order to identify which parameters are more important than others through numerical simulation. This study is indispensable to design lumbar belts. For this purpose, we selected 11 variables according to several clinical tests:

- $\quad$ on the patient: size (fat or slim), height (tall or small), hollow-back (hyper or hypo),

- $\quad$ on the belt: height (2 values), type by varying its linear tension,

- on the mechanical properties: abdomens, other soft tissues of the trunk, annulus, nucleus, bone and skins.

\section{Methods}

The 3D geometry of the trunk was acquired by parameters measurement in lateral radiography (vertebral length, width and endplate slope) and in patients (bust, waist, hips and stature measurement). Thanks to these parameters, a generic model with six components (vertebras, annulus, nucléus, illiac crests, abdomen and other soft tissues) has been built. All components are represented by tetrahedral elements.

Mechanical properties of all the components of the model were taken from published data [Goel, 1993], [Sylvestre, 2007], [Clin, 2011]. Its mechanical behaviour was considered as linear elastic.
A pressure was applied onto the trunk to simulate lumbar belt wearing. The surface of applied pressure in the model was the same than the area applied on the patient by the belt. Pressure was calculated by the Laplace's law [Dubuis, 2012]:

$$
\mathrm{P}=\mathrm{T} / \mathrm{R}
$$

\begin{tabular}{|c|c|c|}
\hline Variables & $\begin{array}{c}\text { Upper and } \\
\text { lower bounds }\end{array}$ & $\begin{array}{l}\text { Type of } \\
\text { variable }\end{array}$ \\
\hline Morphology & fat or slim & binary \\
\hline Height & tall or small & binary \\
\hline Hollow-back & hyper or hypo & binary \\
\hline Height of the belt & 21 or $26 \mathrm{~cm}$ & binary \\
\hline Type of the belt & $\begin{array}{c}\text { Lumbaskin }{ }^{\circledR} \\
\text { or Lombacross } \\
\text { Activity }{ }^{\circledR}\end{array}$ & binary \\
\hline Abdomen & 0.01 to $1 \mathrm{MPa}$ & continuous \\
\hline $\begin{array}{l}\text { Soft tissue of the } \\
\text { trunk }\end{array}$ & 0.55 to $1 \mathrm{MPa}$ & continuous \\
\hline Annulus & 4 to $14.9 \mathrm{MPa}$ & continuous \\
\hline Nucleus & 3 to $8 \mathrm{MPa}$ & continuous \\
\hline Bone & $\begin{array}{c}1000 \text { to } 12000 \\
\mathrm{MPa}\end{array}$ & continuous \\
\hline Skin & 1 to $5 \mathrm{MPa}$ & continuous \\
\hline
\end{tabular}

Table 1 Chosen variable for parametrical study.
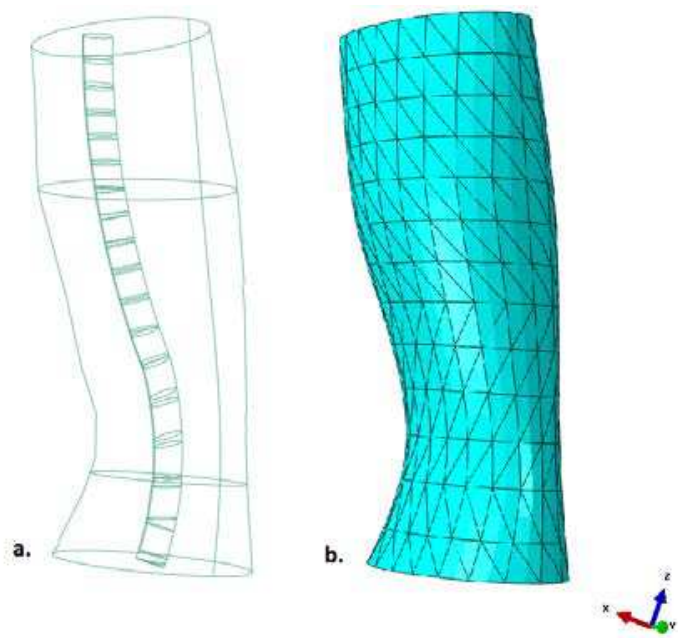

Figure 1 Finite element model of the trunk, a. Entire geometric model, b. Meshing model. 
with $\mathrm{P}$ the pressure, $\mathrm{T}$ the line tension and $\mathrm{R}$ the radius of curvature. Linear tension varies with lumbar belt type. As a consequence, mean pressure was between 4 and $13 \mathrm{kPa}$.

Different boundary conditions were also studied to make sure the validity of the numerical model, because they might give a great influence on the results. Finally, we took the followings: upper surface of the trunk was blocked to only allow translation in longitudinal direction and in lower surface, axis in the frontal plane passing trought the illiac crests was blocked.

Parameters was studied by a design of experiments, built by a stratified Latin hypercube methods with 100 experiments. The output parameters are the abdominal pressure, the interdiscal pressure and the lordosis.

Lumbar belt simulation was evaluated thanks to a clinical study by the comparison of the volume variation of the trunk with and without wearing a lumbar belt. Measured pressure during clinical study and applied pressure in the numerical model were compared.

\section{Results and Discussion}

Figure 1 shows the finite elements model of the trunk. According to the convergence test, optimal model contains more than 1200000 elements with more than 1600000 nodes.

Modification of the spine posture is characterized by the existence of a displacement gradient (up to $3 \mathrm{~mm}$ for the trunk and $2.5 \mathrm{~mm}$ for the spine). The mean abdominal pressure variation is $10 \mathrm{kPa}$ when the stiffer lumbar belt is used (mean applied pressure of $13 \mathrm{kPa}$ ).

Interface pressure applied to the model according to the Laplace's law is equivalent to pressure applied by the lumbar belt to a patient according to the clinical study. Volume variation of the trunk when wearing a lumbar belt are equivalent between the numerical and clinical studies.

Parameters having the greatest influence on the abdominal and intradiscal pressure is the mechanical properties of abdomen, annulus, nucleus and other soft tissues. Height and type of lumbar belts have influence on lordosis. Morphology of patients seems to have no significant influence on the three output parameters.

\section{Conclusion and future works}

This project was a first parametrical study on the mechanical and physiological impact of lumbar belts. It is a first step to a global numerical and experimental study. It permit to understand wich parameters have significant influence on the abdominal, intradiscal pressures and the lordosis when wearing a lumbar belt.

Next steps of this study are the comparison of numerical results to clinical ones (interface pressure and displacement measurement) and the numerical simulation of patient specific models.

\section{References}

Calmels P, Queneau P, Hamonet C, Le Pen C, Maurel F, Lerouvreur P, Thoumie P. 2009. Effectiveness of a lumbar belt in subacute low back pain : an open, multicentric, and randomized clinical study. Spine. 34(3):215220.

Clin J, Aubin CE, Lalonde N, Parent S and Labelle H. 2011. A new method to include the gravitational forces in a finite element model of the scoliotic spine. Med Biol Eng Comput. 49:967-977.

Dubuis L, Avril S, Debayle J and Badel P. 2012. Identification of the material parameters of soft tissues in the compressed leg. Comput Methods Biomech Biomed Engin. 15(1):3-11.

Fassier JB. 2011. Prévalence, coûts et enjeux sociétaux de la lombalgie. Revue du Rhumatisme. 78(supplement 2):S38-S41.

Goel VK, Kong W, Han JS, Weinstein JN and Gilbertson LG. 1993. A combined finite element and optimization investigation of lumbar spine mechanics with and without muscles. Spine. 18(11):1531-1541.

Leclerc A, Gourmelen J, Chastang JF, Plouvier S, Niedhammer I and Lanoë JL. 2009. Level of education and back pain in France: the role of demographic, lifestyle and physical work factors. Int Arch Occup Environ Health. 82(5):643-652.

Périé D, Aubin CE, Lacroix M, Lafon Y and Labelle H. 2004. Biomechanical modeling of orthotic treatment of the scoliotic spine including a detailed representation of the bracetorso interface. Med Biol Eng Comput. 42(3):339-344.

Sylvestre PL, Villemure I and Aubin CE. 2007. Finite element modeling of the growth plate in a detailed spine model. Med Biol Eng Comput. 45:977-988. 